\title{
PENINGKATAN LAJU DISOLUSI ATORVASTATIN DENGAN DISPERSI PADAT MENGGUNAKAN PEMBAWA KARAGENAN
}

\author{
Deny Puriyani Azhary', Dadih Supriadi' ${ }^{1}$, Yanni Dhiani Mardhiani ${ }^{1}$, Sinta Agustina1 \\ ${ }^{1}$ Fakultas Farmasi Universitas Bhakti Kencana \\ J1. Soekarno Hatta No. 754, Cibiru, Bandung \\ Email : deny.puriyaniazhari@stfb.ac.id
}

\begin{abstract}
ABSTRAK
Atorvastatin suatu obat antihiperlipidemia golongan statin termasuk kedalam BCS kelas II yang ditandai dengan kelarutan rendah dan permeabilitas tinggi. Kelarutan yang rendah dalam air menyebabkan laju disolusi obat tersebut rendah dan dapat mempengaruhi bioavailabilitasnya. Salah satu cara untuk meningkatkan laju disolusi obat yaitu dengan sistem dispersi padat. Tujuan penelitian ini untuk meningkatan laju disolusi atorvastatin dengan dispersi padat. Sistem dispersi padat dibuat dengan metode kneading menggunakan karagenan sebagai pembawa. Dispersi padat dibuat dengan variasi perbandingan atorvastatin : karagenan 1:1; $1: 3$ dan $1: 5 \mathrm{~b} / \mathrm{b}$. Sifat padatan serbuk dispersi padat dievaluasi dengan metode analisa difraksi sinar-X, mikroskopik SEM, termal DSC, spektrokopik FTIR. Profil disolusi dilakukan dalam medium dapar phospat $\mathrm{pH}$ 6,8 dengan alat uji disolusi tipe I USP. Hasil analisa difraksi sinar-X, mikroskopik SEM, termal DSC dan spektrokopik FTIR menunjukkan fase kristalin atorvastatin mengalami penurunan derajat kristalinitas dan pembentukan fase amorf. Profil disolusi menunjukan bahwa dispersi padat atorvastatin memiliki nilai laju disolusi yang lebih tinggi dibandingkan dengan atorvastatin murni. Penelitian ini menunjukkan bahwa pembentukan dispersi padat atorvastatin dengan karagenan sebagai pembawa dapat meningkatkan laju disolusi atorvastatin.
\end{abstract}

Kata kunci: Atorvastatin, karagenan, dispersi padat, laju disolusi

\begin{abstract}
Atorvastatin is one of the statin antihyperlipidemia drugs belonging to class II BCS which is characterized by low solubility and high permeability. Low solubility in water causes the dissolution rate of the drug to be low and can affect its bioavailability. One way to improve the dissolution rate of drug is by a solid dispersion system. The purpose of this study is to improve the dissolution rate of atorvastatin with solid dispersion. The solid dispersion system is made by kneading method using carrageenan as a carrier. Solid dispersion was prepared with several variations of atorvastatin to carrageenan $1: 1 ; 1: 3$ and $1: 5 \mathrm{w} / \mathrm{w}$. Solid state properties of solid dispersion system were evaluated by X-ray diffraction analysis methods, microscopic SEM, thermal DSC, spectroscopic FTIR. The dissolution profile was carried out in phosphate buffer medium $\mathrm{pH} 6.8$ by using dissolution tester apparatus type II USP. The results of X-ray diffraction analysis, SEM microscopic, DSC thermal and FTIR spectrocopic showed that the atorvastatin crystalline phase decreased in the crystallinity index and formation of amorphous phase. The dissolution profile shows that the atorvastatin solid dispersion had faster dissolution rate than intack atorvastatin. This study shows that the formation of atorvastatin solid dispersions with carrageenan as a carrier can improve the dissolution rate of atorvastatin.
\end{abstract}

Keywords: Atorvastatin, carrageenan, solid dipersion, dissolution rate 


\section{PENDAHULUAN}

\subsection{Latar Belakang}

Obat dengan kelarutan rendah dalam air menyebabkan laju disolusinya rendah pula, sehingga konsentrasi efektif minimum obat dalam darah (bioavailabilitas) tidak tercapai dan efek terapi tidak diperoleh. Salah satu obat yang memiliki kelarutan rendah dalam air adalah atorvastatin.

Atorvastatin adalah obat hiperlipidemia golongan statin yang termasuk ke dalam BCS (Biopharmaceutical Classification System) kelas II, yang ditandai dengan kelarutan rendah dan permeabilitas tinggi, dengan nilai bioavailabilitas sebesar $12 \%$ (British Pharmacopoeia, 2012).

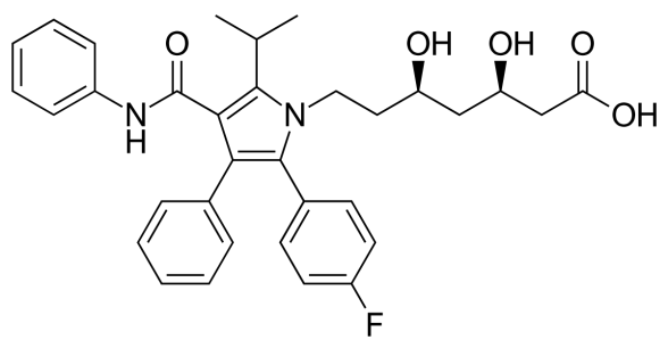

Gambar 1. Struktur Kimia Atorvastatin.

Bioavailabilitas yang kecil dapat dijadikan indikasi bahwa obat tersebut memiliki laju disolusi yang rendah. Disolusi atorvastatin dapat meningkat melalui proses mikrokristalisasi, modifikasi kristal dan sistem dispersi padat (Gozali D, 2015). Dispersi padat pertama kali dimanfaatkan oleh Sekiguchi dan Obi untuk meningkatkan kelarutan dan absorbsi secara per oral dari obat yang memiliki kelarutan yang rendah di dalam air Dispersi padat didefinisikan sebagai sistem dispersi satu atau lebih bahan aktif ke dalam suatu pembawa atau matriks inert dalam kondisi padat, yang dibuat dengan cara peleburan, pelarutan, atau kombinasi dari peleburan dan pelarutan (Dhirendra $\mathrm{K}$, Lewis $\mathrm{S}$, Udupa N, and Atin K., 2009). Dalam sistem dispersi padat penambahan polimer sebagai pembawa/matriks menjadi hal yang penting. Polimer sintetis telah banyak digunakan dari penelitian sebelumnya, seperti polimer selulosa (HPMC) atau derivat pirolidon (PVP) (Soo Kim, et al., 2013) dan polimer polietilenglikol 6000 (Gozali, D., 2015). Penggunaan polimer alam belum banyak digunakan untuk sistem dispersi padat. Salah satu polimer yang sudah digunakan yaitu karagenan, merupakan polisakarida yang terkandung dalam beberapa spesies rumput laut atau alga merah (Rhodophyceae). Polisakarida ini merupakan hidrokoloid yang melimpah ketiga di dunia setelah pati dan gelatin (Mustapha, et al., 2011). Hidrokoloid memiliki karakteristik yang dapat menyerap dan mengikat air dengan baik (Herawati H, 2018). Karagenan sendiri mempunyai daya mengembang yang cukup tinggi sehingga cocok untuk menjadi basis sediaan yang dapat melepaskan obat dengan cepat. Polimer karagenan telah dimanfaatkan sebagai pembawa dalam dispersi padat untuk meningkatkan kelarutan obat 
Peningkatan Laju Disolusi Atorvastatin...

Efavirenz, dimana disolusi obat meningkat pada menit ke 60 menjadi $76-86 \%$ dengan teknik kneading (Hari Vedha, l. 2012).

\subsection{Rumusan Masalah}

Dari latar belakang yang telah diuraikan, maka dapat dirumuskan suatu permasalahan yaitu apakah penambahan polimer alam karagenan dapat meningkatkan laju disolusi atorvastatin.

\subsection{Tujuan Penelitian}

Untuk mengetahui peningkatan laju disolusi atorvastatin dengan sistem dispersi padat menggunakan pembawa karagenan.

\subsection{Manfaat Penelitian}

Memberikan informasi tentang peningkatan laju disolusi atorvastatin dengan sistem dispersi padat menggunakan pembawa karagenan.

\section{METODE PENELITIAN}

\subsection{Alat dan Bahan}

Timbangan analitik, dissolution tester, spektrofotometer UV, Scanning Electron Microscope (SEM), alat difraksi sinar-X, FTIR, atorvastatin; karagenan; buffer fosfat $\mathrm{pH} 7,4 ; \mathrm{NaOH}$ dan aquadest.

\subsection{Pembuatan Campuran Fisik (CF)}

Atorvastatin dan karagenan dicampur dalam mortir dan digerus selama 5 menit, kemudian diayak dengan ayakan no. 80.
2.3 Pembuatan Dispersi Padat Atorvastatin-Karagenan dengan Metode Kneading.

Atorvastatin dan karagenan ditimbang secara akurat dengan perbandingan (atorvastatin : karagenan) 1:1; 1:3 dan 1:5 (F1, F2 dan F3) kemudian dipindahkan ke mortir. Selanjutnya ditambahkan air panas sampai terbentuk konsistensi pasta. Pasta yang dihasilkan kemudian dikeringkan dalam oven pada suhu $45^{\circ} \mathrm{C}$ selama 24 jam. Sistem dispersi padat yang telah kering digerus dalam mortir kemudian diayak dengan ayakan no.80 (Hari Vedha, et al 2012).

\subsection{Analisis Difraksi Sinar-X}

Perubahan sifat padatan sistem dispersi padat diamati dengan analisis difraksi sinar-X menggunakan difraktometer sinar-X (PANalytical X'Pert PRO Seri pw3040/XO, Netherlands). Analisis dilakukan pada sudut difraksi $2 \Theta$ $5^{\circ}-50^{\circ}$.

\subsection{Analisis Morfologi Partikel dengan Scanning Electron Microscope (SEM)}

Pengamatan morfologi partikel dilakukan dengan alat SEM (JEOL JSM6360 LA, Japan). Sampel disalut dengan lapisan tipis gold palladium pada kondisi vakum. Kemudian sampel serbuk di-scan dan mikrofoto diambil dengan alat SEM pada perbesaran yang tepat. 


\subsection{Analisis Spekroskopi FT-IR}

Spektrum inframerah atorvastatin dan sistem dispersi padat diperoleh dengan alat Spektrofotometer FT-IR (Thermo Scientific, USA). Sampel didispersikan dalam serbuk kalium bromida dan dikompresi menjadi pellet. Spektrum sampel direkam pada bilangan gelombang $400-3500 \mathrm{~cm}^{-1}$.

\subsection{Uji Disolusi}

Pengujian menggunakan alat disolusi tipe I (keranjang) dengan kecepatan 50 rpm pada suhu $37^{\circ} \pm 0,5^{\circ} \mathrm{C}$. Medium disolusi yang digunakan yaitu buffer fosfat $\mathrm{pH}$ 7,4. Pengujian dilakukan terhadap atorvastatin murni, campuran fisik dan dispersi padat. Ditimbang cuplikan setara dengan $10 \mathrm{mg}$, kemudian dimasukkan ke dalam wadah disolusi yang telah berisi $900 \mathrm{~mL}$ media disolusi. Pada menit ke 10, 15, 30, 45, dan 60 diambil cuplikan sebanyak $5 \mathrm{~mL}$ dan segera diganti dengan $5 \mathrm{~mL}$ medium disolusi yang sama. Kemudian cuplikan diukur dengan menggunakan alat spektrofotometer UV.

\section{HASIL DAN PEMBAHASAN}

Hasil pengujian difraksi sinar-X dapat dilihat pada gambar 2 .

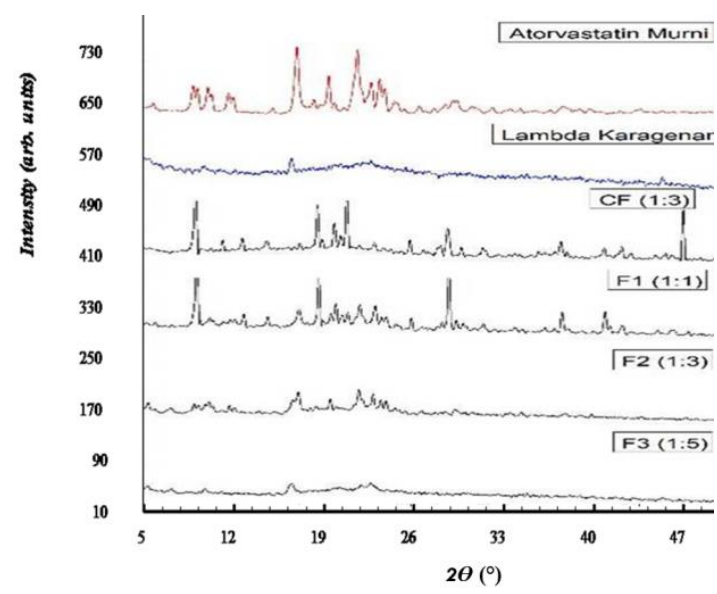

Gambar 2. Difraktogram sinar-X

Pada gambar 2, atorvastatin murni terlihat puncak-puncak difraksi dengan intensitas cukup tinggi, pada $2 \Theta 16,95$; 19,35 dan 23,62 menunjukkan bahwa atorvastatin bersifat kristalin. Difraktogram polimer karagenan menunjukkan pola difraktogram polimer yang khas untuk padatan amorf. Pada campuran fisik (CF) dan sistem dispersi padat (F1) (1:1) puncak difraksi khas masih terlihat, tetapi ada penurunan intensitas dan pada dispersi padat (1:3) fase kristalin mengalami penurunan secara bermakna. Dispersi padat atorvastatin: karagenan 1:5, puncak khas tersebut tidak terlihat lagi. Hal ini menunjukkan terjadinya penurunan derajat kristalinitas serta terbentuknya fase amorf atorvastatin dalam sistem dispersi padat. 

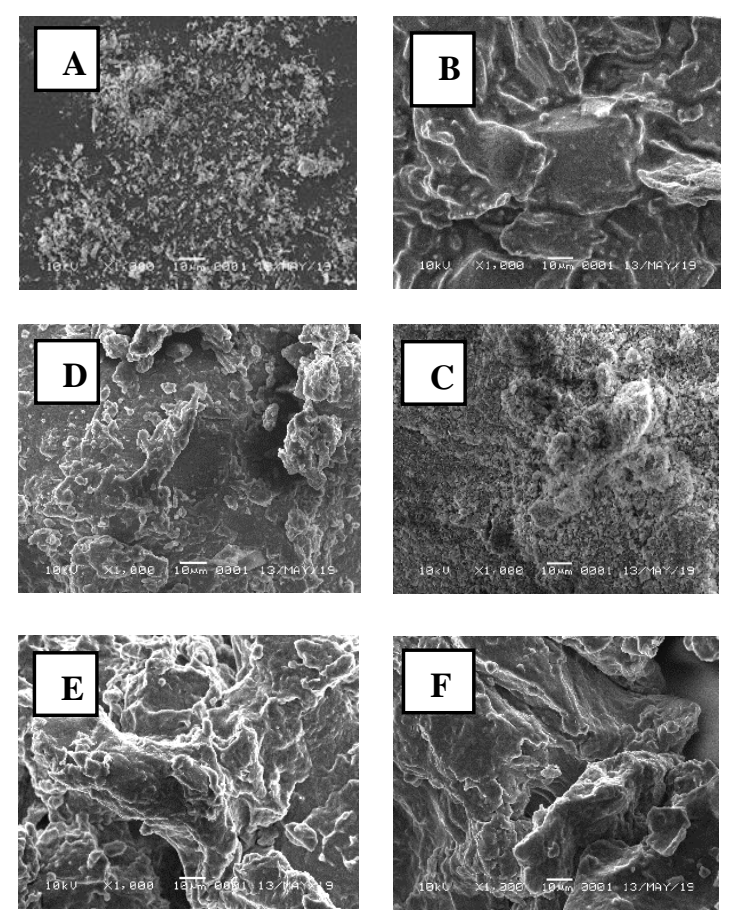

Gambar 3. Hasil uji SEM: A) atorvastatin murni, B) karagenan, C) CF 1:1, D) DP 1:1, E) DP 1:3 dan F) DP 1:5

Dari gambar 3, (A) menunjukkan bahwa senyawa padatan atorvastatin memiliki morfologi dan habit kristal kecil dan teratur. Sedangkan pada polimer karagenan (B) memiliki bentuk lebih amorf, ditandai dengan sisi dari partikel yang tidak tajam dan memiliki ukuran padatan yang lebih besar dari atorvastatin. Pada sistem dispersi padat, morfologi dan habitnya tidak begitu jelas serta tidak bisa dibedakan antara atorvastatin dan karagenan. Pada dispersi padat perbandingan 1:3 dan 1:5 telah menunjukkan perubahan pada ukuran padatannya yang sesuai morfologi polimer. Hal ini dapat diindikasikan serbuk membentuk dispersi padat, obat dalam partikel halus terperangkap dalam matriks polimer.

Hasil dari pengujian FTIR ditunjukkan pada gambar 4 .

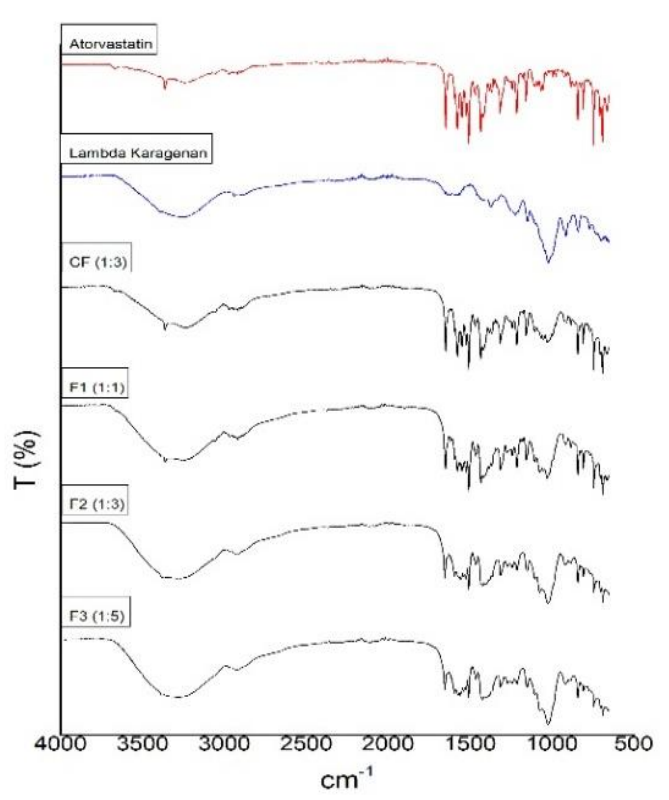

Gambar 4. Hasil pengujian FTIR

Dari gambar 4, atorvastatin menunjukkan beberapa puncak yang khas, terutama pada bilangan gelombang 1595.1 (gugus aromatic $-\mathrm{C}=\mathrm{C}$ ); 1651.7 (gugus $\mathrm{C}=\mathrm{O}$ ); 2903.5 (gugus $-\mathrm{CH}$ ). Adanya kehilangan puncak pada spektrum baru menunjukkan adanya interaksi secara fisika dan kimiawi. Perubahan spektrum pada bilangan gelombang $3100-3400 \mathrm{~cm}^{-1}$ pada sistem dispersi padat atorvastatinkaragenan menunjukkan terbentuknya ikatan hidrogen antara atorvastatin dan karagenan. 
Profil uji disolusi ditunjukkan oleh gambar 5.

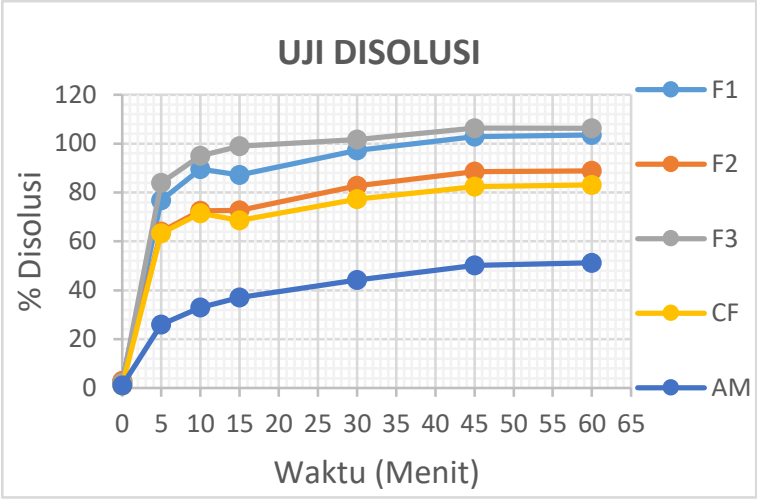

Gambar 5. Profil disolusi atorvastatin murni (AM), campuran fisik (CF) dan sistem dispersi padat $(\mathrm{F} 1, \mathrm{~F} 2, \mathrm{~F} 3)$

Dilihat dari grafik profil uji disolusi, dispersi padat ketiga formula memiliki laju disolusi yang lebih baik dibandingkan dengan campuran fisik dan atorvastatin murni. Hal ini dapat dilihat dari nilai persen terdisolusi pada setiap pengujian yang lebih tinggi. Jumlah polimer sangat berpengaruh terhadap peningkatan kelarutan atorvastatin. Semakin banyak polimer yang digunakan, maka semakin banyak pula jumlah atorvastatin yang terlarut dalam medium, sehingga mempengaruhi pada nilai persen disolusi yang semakin tinggi.

\section{KESIMPULAN}

Sistem dispersi padat atorvastatin dalam pembawa polimer karagenan yang bersifat hidrofilik, dapat menurunkan derajat kristalinitas dari padatan atorvastatin. Penurunan derajat kristalinitas atorvastatin, dapat meningkatkan laju disolusinya.

\section{UCAPAN TERIMAKASIH}

Penulis mengucapkan terima kasih yang sebesar-besarnya pada P3M Sekolah Tinggi Farmasi Bandung yang telah memberikan dana untuk terlaksananya penelitian ini.

\section{DAFTAR PUSTAKA}

British Comission Secretariat. 2012. British Pharmacopeia. London: British Comission Secretariat.

Chivate N, Patil S, Saboji J, dan Chivate A. 2012. A Complete Review on Solid Dispersion Technology and Factorial Design. Current Pharma Research ISSN: 2230-7842 CPR 2(4), 659667.

Dhirendra K, Lewis S, Udupa N, dan Atin K. 2009. Solid Dispersion: A Review. Pak. J. Pharm. Sci., Vol.22, No.2, 234-246.

Gozali, D., Wardhana Yoga W., Shofa. 2015. Formulasi dan Evaluasi Tablet Dispersi Padat Kalsium Atorvastatin. Jurnal Pharmascience. Vol 2. No.2.

Hari Vedha B.N., Begum Yasmin A., Devi Ramya D. 2012. Solid State Modification for the Enhancement of Solubility of Poorly Soluble Drug : Carrageenan as Carrier. International Journal of Applied Pharmaceutics. Vol. 4. Issues $2: 1-7$.

Herawati, Heni. 2018. Potensi Hidrokoloid sebagai Bahan Tambahan pada Produk Pangan dan Nonpangan Bermutu. Jurnal Litbang Pertanian. Vol. 37. No 1 : 17-25.

Mustapha, S., Chandar, H., Abidin, Z.Z., Saghravani, R., Harun, M.Y. 2011. Production of Semi-Refined Carrageenan from Eucheuma cotonii, Journal of Scientific \& Industrial Research, 70: 865-870.

Sharma, Monika, Rajeev Garg, G.G. Gupta. 2013. Formulation and evaluation of Solid Dispersion of Atorvastatin Calcium, Journal of Pharmaceutical and Scientific Innovation, 2(4), 73-81. 
Peningkatan Laju Disolusi Atorvastatin...

Soo Kim Min, Kim JS, Cho W, Park HJ. 2013. Oral Absorption of Atorvastatin Solid Dispersion Based on Cellulose or Pyrrolidone Derivate Polymer. International Journal of Biological Macromolecules 59 : 138- 142.

Thommes Markus, Lieven Baert, Gerben AE. 2009. Improved bioavailability of darunavir by use of k-carrageenan versus microcrystalline cellulose as pelletisation aid. European Journal of Pharmaceutics and Biopharmaceutics 72 (2009) 614-62.

Vasoncelos, B. Sarmento dan P. Costa. 2007. Solid Dispersion as Strategy to Improve Oral Bioavailability of Poor Water Soluble Drugs. Drug Discovery Today. 12. 1068-1075.

Vieth M., Siegel MG, Higgs RE, Watson IA, Robertson DH, Savin KA. 2004. Characteristic physical properties and structural fragments of marketed oral drugs. Journal Medical Chem. 47: 224232. 